\title{
Analisis Faktor-Faktor Penyelenggaraan Kebijakan Sekolah Filial bagi Anak Didik Pemasyarakatan di Lembaga Pembinaan Khusus Anak Palembang
}

\author{
Ade Afrilia Ardinda*, Roy Valiant** \\ Universitas Indonesia
}

Diterima Februari 2019; Disetujui April 2019; Dipublikasikan Juni 2019

\begin{abstract}
Abstrak
Secara umum, penelitian ini bertujuan untuk mengetahui faktor-faktor yang mempengaruhi penyelenggaraan pembinaan anak didik pemasyarakatan yang berbasis pendidikan di Lembaga Pembinaan Khusus Anak Palembang. Penelitian ini menggunakan pendekatan post-positivis dan metode kualitatif untuk menjelaskan mengenai analisis faktor-faktor yang mempengaruhi penyelenggaraan pembinaan anak didik pemasyarakatan yang berbasis pendidikan yang dilakukan di LPKA Palembang dengan melihat aspek konten dan konteks sebagai suatu kebijakan. Dengan melihat permasalahan ini, peneliti menggunakan teori implementasi kebijakan dari Merilee S Grindle untuk mendukung proses analisis faktor-faktor yang mempengaruhi penyelenggaraan pembinaan anak didik pemasyarakatan yang berbasis pendidikan di LPKA Palembang. Ketika anak berhadapan dengan hukum, anak harus diposisikan sesuai dengan Undang -Undang Sistem Peradilan Pidana Anak. Pelaksanaan program pembinaan yang ada masih belum sesuai dengan kebutuhan anak didik pemasyarakatan serta kurang memberikan manfaat yang mereka harapkan. Sehingga, anak didik pemasyarakatan kehilangan minat untuk mengikuti kegiatan yang dilaksanakan oleh LPKA. Hal ini menunjukkan bahwa ada hal yang luput dari perhatian pihak LPKA terkait dengan proses pembinaan bagi anak didik pemasyarakatan. Hasil diskusi menunjukkan kendala-kendala penyelenggaraan pembinaan anak berbasis pendidikan antara lain kendala fasilitatif yang berupa kondisi bangunan dan sarana penunjang pelaksanaan pendidikan, anggaran, peserta didik, serta standar penyelenggaraan pendidikan.
\end{abstract}

Kata Kunci: Sekolah Filial, LPKA, Implementasi Kebijakan

Abstract

The paper aims to know factors that affect educational based implementation of child correctional service in Palembang correctional facility or Lembaga Pembinaan Khusus Anak (LPKA). Public policy implementation is one of Public Administration interest. The research uses post-positivism approach and qualitative method to explain the factors analysis that affect educational based correctional service implementation of child prisoner in LPKA Palembang by considering content and context aspects of implementation. Policy implementation theory by Merilee S. Grindle is used to support the factors analysis. When children are faced with law, that have to be positioned in accoradance with the Chlid Criminal Justice System Act or Undang-Undang Sistem Peradilan Pidana Anak. Their condition are not completely their fault. Social control from socialitation agent that is weak could cause a child do deviance. Correctional srevice program implementation have still not yet approriate with children needs and expecations. Child prisoner then lose interest to take part in activities held by LPKA. It shows there is something missing from LPKA's attention about child correctional service process. Discussion results show some educational based children correctional service implementation obstacles i.e. facilities (building and supporting facilities), budget, the child prisoner, and education implementation standard. Public policy is not only about the rules and acts but also have to overview and analyze the policy implementation in the field.

Key Words: Filial School, Child Prisoner, Merilee Grindle, Policy

How to Cite : Ardinda A.A, Roy Valiant, R (2019). Analisis Faktor-Faktor Penyelenggaraan Kebijakan Sekolah Filial bagi Anak Didik Pemasyarakatan di Lembaga Pembinaan Khusus Anak Palembang, 7 (1) 2019:72-86

*Corresponding author: ISSN 2549-9165 (Print)

Email: adeafriliaadinda@gmail.com ISSN 2580-2011 (Online) 


\section{PENDAHULUAN}

Era globalisasi yang semakin pesat menuntut perubahan dalam berbagai bidang dan memacu adanya perbaikan sistem terus menerus menuju kearah yang lebih baik dari sebelumnya. Demikian juga halnya dengan bidang pelayanan pemerintah pada umumnya, yang dicerminkan oleh kinerja birokrasi pemerintah (Sinambela, 2008). Begitu juga yang dihadapi oleh organisasi

birokrasi seperti Lembaga Pemasyarakatan, salah satu Unit Pelaksana Teknis pada Direktorat Jenderal Pemasyarakatan, Departemen Hukum dan Hak Asasi Manusia Republik Indonesia. Secara sosiologis pemasyarakatan menyelenggarakan pelayanan publik dalam dua tataran, yaitu pelayanan secara makro dan pelayanan secara mikro (Simanjuntak, 2009). Pemasyarakatan melaksanakan pelayanan makro yang berhubungan dengan tugas dan fungsinya dalam rangka pembinaan para pelanggar hukum. Ketika pelanggaran yang dilakukan seseorang berada dalam kualitas yang tidak bisa ditolerir oleh rasa keadilan masyarakat, negara (dalam hal ini pemasyarakatan) mengambil alih peran pembinaannya agar yang bersangkutan menjadi warga masyarakat yang baik dan berguna (Simanjuntak, 2009). Sementara pelayanan masyarakat dalam skala mikro adalah pelayanan Pemasyarakatan terhadap hak-hak pelanggar hukum yang dijamin oleh Undang-Undang Nomor 12 Tahun 1995 tentang Pemasyarakatan, sekurangnya ada empat belas macam hak yang melekat pada seorang narapidana (Simanjuntak, 2009).

Terjadi perubahan nomenklatur, Lembaga Pemasyarakatan Anak yang dulu kita kenal berubah nama menjadi Lembaga Pembinaan Khusus Anak, perubahan nomenklatur ini sesuai dengan amanat Undang-Undang Nomor 11 Tahun 2012 tentang Sistem Peradilan Pidana Anak (SPPA) dan instruksi lisan Presiden Joko Widodo kepada Menteri Hukum dan HAM Yasonna H. Laoly. Diharapkan perubahan nama ini tak sekedar perubahan nomenklatur atau pembentukan organisasi baru, namun pada perwujudan transformasi penangangan terhadap anak yang berhadapan dengan hukum $(\mathrm{ABH})$, termasuk mengganti kesan hukuman menjadi pendekatan berbasis HAM utamanya tentang budi pekerti, dan yang juga akan dihilangkan kesan angker pada lembaga pemasyarakatan 
yang tak dipungkiri masih melekat hingga sekarang (Yulianto dan Ernis, 2016).

Pembinaan intelektual (kecerdasan) dapat dilakukan baik melalui pendidikan formal maupun melalui pendidikan non-formal. Pendidikan formal diselenggarakan sesuai dengan ketentuan-ketentuan yang telah ada yang ditetapkan oleh pemerintah agar dapat ditingkatkan semua warga binaan pemasyarakatan (Keputusan Menteri Kehakiman RI, 1990). Berdasarkan Pasal 4, 5 dan 6 UU Sisdiknas dapat disimpulkan bahwa anak yang ditempatkan dalam LPKA juga berhak mendapatkan pendidikan tanpa dibeda-bedakan dan pemerintah bertanggung jawab atas penyelenggaraan pendidikan tersebut.

Pendidikan yang diberikan pada anak dapat berupa pendidikan formal, informal maupun nonformal yang dapat saling melengkapi dan memperkaya (Pasal 13 (1) UU Sisdiknas). Pendidikan formal terdiri atas pendidikan dasar, pendidikan menengah, dan pendidikan Tinggi (Pasal 14 UU Sisdiknas) (Aprilianda, 2014). Dengan melihat kondisi diatas, maka anak dalam menjalani masa pembinaan di lembaga pembinaan berhak mendapatkan hak- hak yang sepatutnya mereka terima termasuk hak mendapatkan kesempatan sekolah. Kebijakan pola pembinaan harus tetap mengedepankan kepentingan terbaik bagi anak. Menurut Undang-Undang Nomor 11 tahun 2012 tentang Sistem Peradilan Pidana Anak, pasal 1 angka 3 yang dimaksud anak adalah anak yang telah berumur 12 (dua belas) tahun, tetapi belum berumur 18 (delapan belas) tahun (Prakoso, 2013).

Anak merupakan generasi penerus bangsa yang akan bertanggungjawab terhadap eksistensi dari bangsa di masa yang akan datang. Anak perlu dibantu oleh orang lain dalam melindungi dirinya, terkhusus ketika anak sedang berhadapan dalam sistem peradilan anak. Penanganan terhadap perilaku menyimpang yang dilakukan oleh anak merupakan perhatian dunia. Juvenile deliquency tidak timbul secara spontan tetapi ia melalui berbagai tahap sesuai dengan kematangan jiwa individu tersebut dengan dipengaruhi oleh sejumlah faktor. Diantaranya faktor keluarga, lingkungan, sekolah, kondisi ekonomi dan teman sebaya ikut mempengaruhi perilaku dari seorang individu.

Kebijakan pola pembinaan yang tepat turut membantu kondisi 
perkembangan anak di kemudian hari, ketika mereka bebas maupun terlepas dari hukuman. Ketika mereka keluar dari masa hukumannya, anak didik pemasyarakatan ini akan bertemu dan berinteraksi secara langsung dengan masyarakat, sistem pendidikan untuk masa depan mereka dan sebagainya. Pendidikan di dalam Lembaga Pemasyarakatan (Lapas) tidak luput dari perhatian Pemerintah Provinsi Sumatera Selatan. Berbagai bentuk dukungan terhadap dunia pendidikan di dalam lembaga pemasyarakatan terus digulirkan Pemerintah Provinsi Sumatera Selatan (Noerdin, 2016). Dengan minimnya pendidikan yang didapatkan oleh anak didik pemasyarakatan di LPKA, maka pihak LPKA selaku pelaksana harus dapat memberikan pembinaan yang lebih terhadap pendidikan. Salah satu upaya yang dilakukan dengan adanya sekolah filial bagi anak didik yang ada di lembaga pembinaan khusus anak. Sehingga dengan adanya sekolah ini bisa menghilangkan kesan menyeramkan bagi anak didik pemasyarakatan.

Dengan adanya sekolah filial bisa memfasilitasi anak didik pemasyarakatan yang menjalani masa hukuman atau pembinaan di LPKA tetap dapat melanjutkan pendidikannya atau tidak putus sekolah. Keberadaan sekolah filial tersebut tidak hanya mencegah anak-anak yang menjadi warga binaan putus sekolah, tetapi juga memberikan dampak positif meminimalkan jumlah anak yang masuk ke LPKA atau menjadi residivis anak (Sumsel Antaranews, 2017). Pendidikan anak yang diselenggarakan di LPKA terdiri dari Pendidikan Formal dan Non Formal. Pendidikan Formal terdiri dari pendidikan wajib belajar 9 tahun/ SD, SMP dan SMA, sedangkan Pendidikan Non Formal mencakup Kejar Paket A untuk tingkat SD, Paket B untuk tingkat SMP dan Paket C untuk tingkat SMA (Direktorat Bimkemas dan Pengentasan Anak).

Program paket ini dilaksanakan di Lembaga Pemasyarakatan Anak. Namun, setelah terjadi pergantian nama menjadi Lembaga Pembinaan Khusus Anak Palembang, program paket A,B, dan C diganti dengan menyesuaikan kurikulum yang berlaku pada sekolah induk. Sehingga anak didik

pemasyarakatan mendapatkan pendidikan yang sama dengan anak sekolah pada umumnya. Sekolah filial yang dibentuk di LPKA Palembang ini untuk tingkat sekolah dasar menginduk 
di Sekolah Dasar (SD) Negeri 25, tingkat Sekolah Menengah Pertama (SMP) menginduk di SMP Negeri 22, dan Sekolah Menengah Atas menginduk di SMA Negeri 11 Palembang (Sumsel Antaranews, 2017).

Sekolah filial bagi anak didik pemasyarakatan di Sumatera Selatan merupakan sekolah filial pertama di Indonesia yang diperuntunkan bagi anak didik pemasyarakatan yang berada di Lembaga Pemasyarakatan Khusus Anak. Tujuan utama dalam pembuatan tulisan ini adalah menemukan faktorfaktor yang mempengaruhi penyelenggaraan kebijakan sekolah filial bagi anak didik pemasyarakatan di Lembaga Pembinaan Khusus Anak Palembang. Penulisan ini dibuat dengan mempertimbangkan kajian dari beberapa literatur.

\section{METODE PENELITIAN}

Analisis data merupakan sebuah proses penyederhanan data kedalam suatu bentuk yang lebih sederhana sehingga mudah untuk dipahami. Dengan menggunakan data metode kualitatif, maka metode yang dihasilkan melalui data deskriptif-analitis yang pada nantinya akan lebih banyak menggunakan analisis berupa kata-kata.
Penyajian data dalam penelitian ini berupa teks naratif yang dirancang untuk disusun secara sistematis untuk digunakan dalam menentukan apakah penarikan kesimpulan yang dilakukan benar atau tidak. Dalam melakukan penelitian ini dilakukan dengan memperkaya pemahaman peneliti tentang fenomena sosial yang akan diteliti dengan menggunakan studi kepustakaan. Penelitian dengan studi kepustakaan digunakan dalam mengambil data sekunder yang bisa berasal dari buku, jurnal, artikel, berita maupun hasil penelitian terdahulu yang memiliki isu yang relevan dengan tema penelitian, serta data sekunder yang didapatkan dari Kementerian Hukum dan Hak Asasi Manusia.

dapat mempengaruhi implementasi kebijakan (context of implementation). Proses implementasi kebijakan pada umumnya hanya dapat dimulai apabila tujuan-tujuan dan sasaran yang bersifat umum telah ditetapkan, program-program aksi telah dirancang, dan dana/biaya telah dialokasikan untuk mewujudkan tujuan tersebut (Oktafiansyah, 2009). Hal yang lebih penting dalam proses implementasi adalah suatu kenyataan bahwa keputusan yang dibuat pada 
tahap rancangan dan formulasi sangat

berpengaruh terhadap cara kerja

implementasinya. Oleh karena itu,

formulasi kebijakan yang akan

dihasilkan dan bentuk program yang

akan dihasilkan merupakan faktor- faktor yang menentukan keberhasilan

program-program yang akan

dilaksanakan (Meikhurniawati, 2009).

\section{Bagan 2.1 Implementasi sebagai suatu Proses Politik dan Administratif}

(Grindle, 1980)

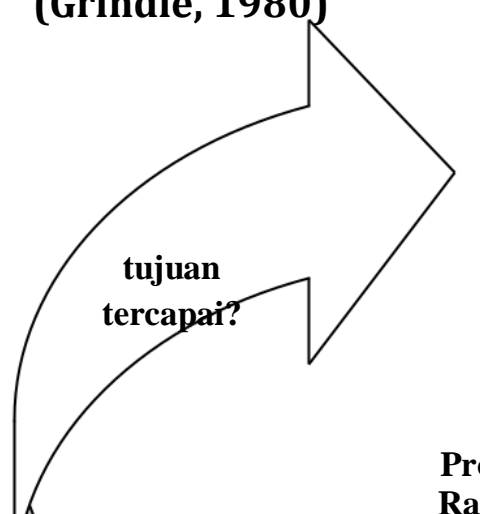

Tujuan Kebijakan

Rancangan Proyek

Individual dan Pendanaan
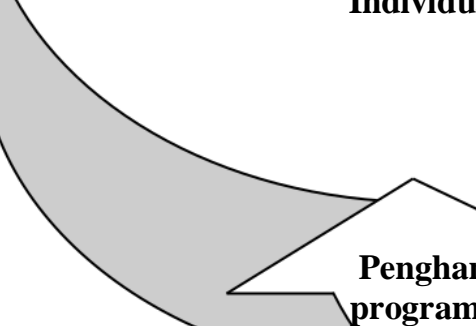

Penghantaran

program sesue

rancangan?

HASIL

DAN

PEMBAHASAN

Kebijakan pembinaan yang

ada di Lembaga Pembinaan Khusus

Anak harus sesuai dengan implementasi kepentingan dan kebutuhan anak setelah keluar dari Lembaga Pembinaan Khusus Anak. Hal ini dikarenakan, untuk kepentingan terbaik bagi anak maupun untuk menjadikan anak didik pemasyarakatan merasakan perlakuan yang sama dengan anak pada umumnya; seperti contoh dalam
Aktivitas Implementasi $\longrightarrow$ Hasil (Outcomes)

$\uparrow$ Dipengaruhi oleh:

a. Konten Kebijakan

1. kepentingan yang terdampak

2. jenis keuntungan

3. perubahan yang diharapkan

4. tempat pembuatan keputusan

5. implementor program

6. sumber daya

b. Konteks Implementasi

1. kekuasaan, kepentingan, dan strategi para aktor yang terlibat

2. karakteristik institusi dan rezim

3. kepatuhan dan responsivitas

a. dampak terhadap masyarakat, individu, dan kelompok

b. perubahan dan penerimaannya 
dari lembaga pembinaan khusus anak

tersebut.

mereka tidak mengulangi kesalahan

Gambar 4.1.

Sebaran Data Warga Binaan Anak dan Tahanan Anak

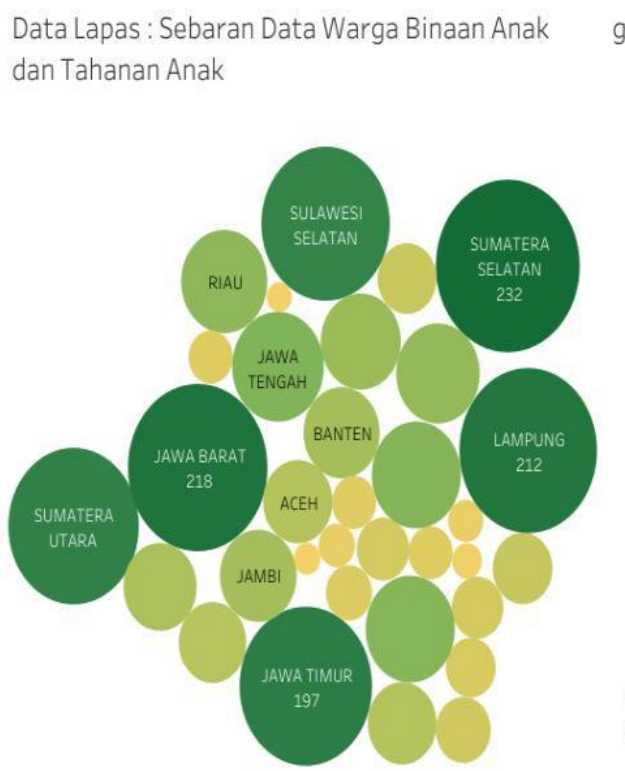

graph
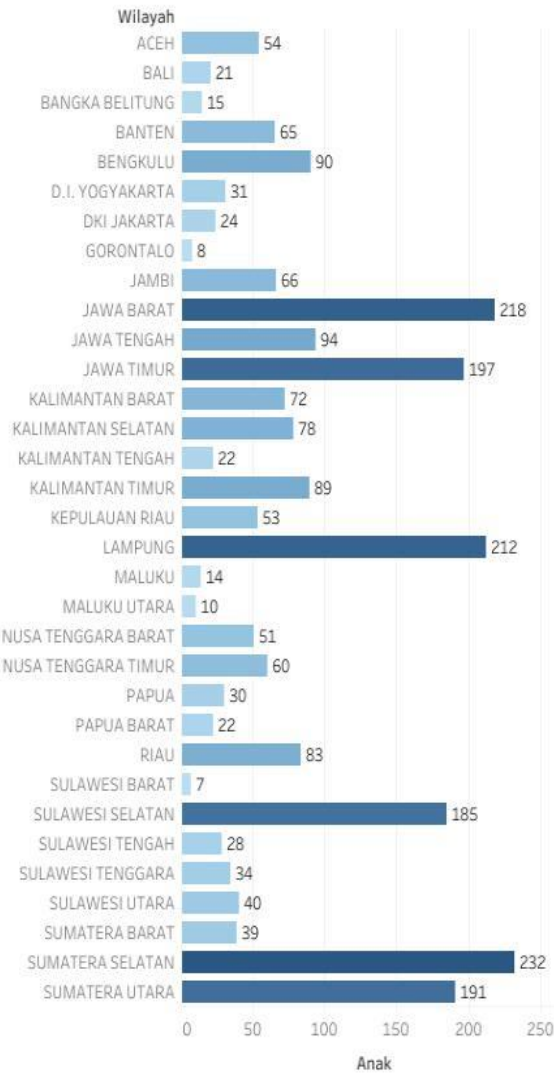

Sumber data tahun 2017: balitbangham

TABEL 4.1. Rekapitulasi Data Jumlah Anak yang Mengikuti Kegiatan Pendidikan Di Lembaga Pembinaan Khusus Anak Kelas I Palembang Kanwil Sumatera Selatan dari Tahun 2015-2017

\begin{tabular}{|c|c|c|c|c|c|c|}
\hline \multirow[b]{2}{*}{ No } & \multirow[b]{2}{*}{ Periode } & \multicolumn{3}{|c|}{ Anak } & \multirow[b]{2}{*}{ Total } & \multirow{2}{*}{$\begin{array}{c}\text { Kegiatan } \\
\text { Anak Peserta } \\
\text { Pendidikan } \\
\end{array}$} \\
\hline & & $\begin{array}{c}\text { Anak } \\
\text { Negara }\end{array}$ & $\begin{array}{c}\text { Anak } \\
\text { Sipil }\end{array}$ & $\begin{array}{c}\text { Anak } \\
\text { Pidana }\end{array}$ & & \\
\hline 1 & Januari & 0 & 0 & 71 & 165 & 259 \\
\hline 2 & Februari & 0 & 0 & 77 & 133 & 250 \\
\hline 3 & Maret & 0 & 0 & 83 & 132 & 100 \\
\hline 4 & April & 0 & 0 & 94 & 129 & 105 \\
\hline 5 & Mei & 0 & 0 & 95 & 118 & 110 \\
\hline
\end{tabular}




\begin{tabular}{|l|l|c|c|c|c|c|}
\hline $\mathbf{6}$ & Juni & 0 & 0 & 87 & 107 & 100 \\
\hline $\mathbf{7}$ & Juli & 0 & 0 & 92 & 115 & 100 \\
\hline $\mathbf{8}$ & Agustus & 0 & 0 & 84 & 146 & 90 \\
\hline $\mathbf{9}$ & September & 0 & 0 & 77 & 122 & 87 \\
\hline $\mathbf{1 0}$ & Oktober & 0 & 0 & 77 & 120 & 85 \\
\hline $\mathbf{1 1}$ & November & 0 & 0 & 79 & 125 & 90 \\
\hline $\mathbf{1 2}$ & Desember & 0 & 0 & 77 & 135 & 193 \\
\hline \multicolumn{6}{l}{} \\
\hline
\end{tabular}

\begin{tabular}{|c|c|c|c|c|c|c|}
\hline \multirow[b]{2}{*}{ No } & \multirow[b]{2}{*}{ Periode } & \multicolumn{3}{|c|}{ Anak } & \multirow[b]{2}{*}{ Total } & \multirow{2}{*}{$\begin{array}{c}\text { Kegiatan } \\
\text { Anak Peserta } \\
\text { Pendidikan }\end{array}$} \\
\hline & & $\begin{array}{c}\text { Anak } \\
\text { Negara }\end{array}$ & $\begin{array}{c}\text { Anak } \\
\text { Sipil }\end{array}$ & $\begin{array}{c}\text { Anak } \\
\text { Pidana }\end{array}$ & & \\
\hline 1 & Januari & 0 & 0 & 76 & 120 & 178 \\
\hline 2 & Februari & 0 & 0 & 97 & 106 & 176 \\
\hline 3 & Maret & 0 & 0 & 90 & 132 & 187 \\
\hline 4 & April & 0 & 0 & 90 & 87 & 179 \\
\hline 5 & Mei & 0 & 0 & 97 & 84 & 100 \\
\hline 6 & Juni & 0 & 0 & 91 & 84 & 90 \\
\hline 7 & Juli & 0 & 0 & 80 & 130 & 80 \\
\hline 8 & Agustus & 0 & 0 & 92 & 109 & 75 \\
\hline 9 & September & 0 & 0 & 80 & 109 & 70 \\
\hline 10 & Oktober & 0 & 0 & 91 & 95 & 70 \\
\hline 11 & November & 0 & 0 & 88 & 99 & 90 \\
\hline 12 & Desember & 0 & 0 & 92 & 89 & 70 \\
\hline
\end{tabular}

TABEL 4.1. Rekapitulasi Data Jumlah Anak yang Mengikuti Kegiatan Pendidikan Di Lembaga Pembinaan Khusus Anak Kelas I Palembang Kanwil Sumatera Selatan dari Tahun 2015-2017

\begin{tabular}{|c|c|c|c|c|c|c|}
\hline \multirow[b]{2}{*}{ No } & \multirow[b]{2}{*}{ Periode } & \multicolumn{3}{|c|}{ Anak } & \multirow[b]{2}{*}{ Total } & \multirow{2}{*}{$\begin{array}{c}\text { Kegiatan } \\
\text { Anak Peserta } \\
\text { Pendidikan }\end{array}$} \\
\hline & & $\begin{array}{c}\text { Anak } \\
\text { Negara }\end{array}$ & $\begin{array}{c}\text { Anak } \\
\text { Sipil }\end{array}$ & $\begin{array}{c}\text { Anak } \\
\text { Pidana }\end{array}$ & & \\
\hline 1 & Januari & 0 & 0 & 99 & 70 & 150 \\
\hline 2 & Februari & 0 & 0 & 93 & 70 & 140 \\
\hline 3 & Maret & 0 & 0 & 105 & 58 & 68 \\
\hline 4 & April & 0 & 0 & 112 & 53 & 12 \\
\hline 5 & Mei & 0 & 0 & 113 & 62 & 25 \\
\hline 6 & Juni & 0 & 0 & 105 & 89 & 15 \\
\hline 7 & Juli & 0 & 0 & 98 & 115 & 15 \\
\hline
\end{tabular}




\begin{tabular}{|l|l|c|c|c|c|c|}
\hline $\mathbf{8}$ & Agustus & 0 & 0 & 89 & 115 & 15 \\
\hline $\mathbf{9}$ & September & 0 & 0 & 102 & 115 & 15 \\
\hline $\mathbf{1 0}$ & Oktober & 0 & 0 & 107 & 115 & 15 \\
\hline $\mathbf{1 1}$ & November & 0 & 0 & 95 & 115 & 15 \\
\hline $\mathbf{1 2}$ & Desember & 0 & 0 & 91 & 115 & 15 \\
\hline \multicolumn{2}{l}{ Sumber : Direktorat Jenderal Pemasyarakatan Tahun $\mathbf{2 0 1 7}$} \\
\hline
\end{tabular}

Berdasarkan tabel 4.1 jumlah Anak yang mengikuti kegiatan pendidikan di Lembaga Pembinaan Khusus Anak Palembang dari tahun 2015-2017 cenderung menurun. Hal ini dapat dilihat pada tahun 2017 jumlah total anak pidana sebanyak 115 orang sementara yang mengikuti kegiatan pendidikan hanya 15 orang. Hal ini berbeda pada tahun 2016 dimana total anak pidana sebanyak 89 orang sementara yang ikut kegiatan pendidikan sebanyak 70 orang. Faktafakta ini tentunya sangat miris, dengan berlakunya Undang-Undang Sistem Peradilan Pidana Anak (UU SPPA).

Pada dasarnya arah pelayanan, pembinaan dan pembimbingan terhadap anak didik pemasyarakatan yang perlu dilakukan oleh petugas ialah memperbaiki tingkah laku anak didik pemasyarakatan agar tujuan pembinaan dapat tercapai. Adapun dasar dari pembinaan terhadap anak didik

pemasyarakatan di Lembaga Pemasyarakatan Anak berpedoman pada keputusan Menteri Kehakiman RI No.M.02-PK.04.10 tahun 1990 tentang pola pembinaan narapidana/tahanan (Sudaryati, 2007). Pelaksanaan pendidikan formal bagi anak di Lapas Anak saat ini belum maksimal.

Hasil pemetaan Lapas Anak tahun 2011 dan 2012 dan wawancara dengan petugas lapas anak dan Bapas mengungkap bahwa tidak semua Lapas Anak dapat menyelenggarakan pendidikan formal, dengan beberapa alasan yaitu (Aprilianda, 2014):

a) Terbatasnya jumlah anak yang memenuhi persyaratan mengikuti pendidikan, khususnya lama pidana

b) Minat anak yang rendah terhadap pendidikan

c) Fasilitas dan sarana pendukung yang minim dan hampir tidak ada

d) Rendahnya dukungan dari sekolah Anak sebelumnya

Kendala selama proses pelaksanaan sekolah filial dimana usia anak yang belajar itu bukan usia sekolah. Sebab, mereka yang masuk lembaga pemasyarakatan ada yang tidak tamat sekolah, bisa lanjut sekolah selama dalam binaan (Palembang Tribunnews, 2017). Fakta ini berdasarkan kenyataan kebanyakan anak yang berkonflik dengan hukum yang akhirnya ditempatkan di lapas/rutan kebanyakan memiliki latar belakang pendidikan putus sekolah (Aprilianda, 2014). Lembaga Pembinaan Khusus Anak Palembang, Sumatera Selatan hingga kini masih mengalami keterbatasan fasilitas pendukung untuk melakukan pembinaan dan pendidikan terhadap anak-anak penghuni lembaga itu (Skalanews, 2015). Selain permasalahan sarana dan prasarana 
masalah anggaran juga merupakan permasalahan dari terlaksananya pola pembinaan melalui sekolah filial tersebut (Kepala Sub Bagian Tata Usaha Umum LPKA Palembang, 2018).

Kendala-kendala Penyelenggaraan Pembinaan Anak berbasis pendidikan (Aprilianda, 2014):

1. Fasilitatif

a. Kondisi Bangunan

Kondisi ini menjadi salah satu kendala dalam mendesain ulang lapas sesuai dengan kebutuhan khusus anak, khususnya dalam mendukung kegiatan pendidikan. Permasalahan klasik yang menjadi penyebab adalah minimnya dana untuk keperluan itu, sehingga yang dilakukan hanyalah "tambal sulam" semampunya, apalagi apabila lapas tidak didukung oleh antusiasme atau semangat penuh dari petugas sebagai SDM pelaksana dan penggerak. Saat ini LPKA yang ada belum bisa dikatakan siap sepenuhnya untuk pelaksanaan berlakunya UU SPPA, khususnya dalam kesiapan bangunan yang ramah Anak untuk pembinaan, pelayanan dan juga pendidikan, walaupun ada rentang waktu 5 (lima) tahun yang diberikan oleh UU SPPA.

b. Sarana Penunjang Pelaksanaan Pendidikan

Hasil pemetaan lapas-lapas anak pada tahun 2011 dan 2012 yang dilakukan jajaran Ditjen Pemasyarakatan menjabarkan bahwa secara umum sarana prasarana yang dimiliki sangat minim dan belum memenuhi kebutuhan pelaksanaan. Sarana penunjang yang paling utama adalah ketiadaan atau minimnya fasilitas ruang belajar untuk pelaksanaan program kesetaraan, ketiadaan ruang khusus untuk belajar,

menjadikan ruangan tertentu mempunyai fungsi ganda. Beberapa sarana prasarana penting selain ruang belajar yang juga minim sebagai

pendukung penyelenggaraan pendidikan, seperti alat-alat belajar, computer, LCD, seragam dan lain-lain.

\section{Anggaran}

Anggaran khusus untuk pelaksanaan pendidikan tidak ada serta minimnya dana untuk perbaikan sarana prasarana yang pada sebagian besar lapas anak perlu perbaikan, bahkan renovasi total. Minimnya anggaran juga berpengaruh pada pemenuhan sarana prasarana penunjang kegiatan pendidikan. Minimnya anggaran untuk pelaksanaan monitoring dan evaluasi pelaksanaan pembinaan pendidikan di Ditjen Pemasyarakatan, khususnya di LPKA. 19 lapas anak yang tersebar di Indonesia seharusnya dilakukan pengawasan dan evaluasi serta pemetaan setiap tahun secara berkelanjutan. Letak lapas anak yang berada di beberapa wilayah Indonesia membuat biaya evaluasi monitoring dan pemetaan menjadi relatif tinggi, namun ini diperlukan untuk mengetahui sejauh mana kegiatan pelaksanaan pembinaan pendidikan dan kendala permasalahan yang nyata di lapangan.

3. Peserta Didik (Anak Didik

Pemasyarakatan) 
Terlaksananya pendidikan di Lapas perlu juga dilihat dari kemampuan peserta didik baik dari sisi psikologis maupun intelektualnya. Karena pada kenyataannya tidak semua anak yang berada di dalam Lapas mempunyai kemampuan dan motivasi yang kuat untuk mengikuti pendidikan baik itu formal maupun non formal. Hal ini tentunya menjadi salah satu faktor terhambatnya atau tidak terlaksananya pendidikan bagi anak yang disebut juga Anak Didik Pemasyarakatan. Selain itu kemampuan intelektual anak yang tidak memungkinkan untuk disamakan dengan anak-anak lain pada umumnya dan masa pidana yang pendek yang tidak memungkinkan anak tersebut untuk mengikuti pendidikan formal atau kesetaraan.

Seperti diungkapkan hasil penelitian Lapas Anak Pria Tangerang dengan Universitas Binus pada Tahun 2013 memberikan gambaran bahwa anak-anak yang berada di dalam Lapas memiliki tingkat intelektual di bawah ratarata. Artinya kemampuan mereka untuk berpikir dan berkonsentrasi tidak bisa dipaksakan untuk menempuh pendidikan sesuai standar pada umumnya mengingat latar belakang anak-anak ini yang mayoritas adalah anak-anak jalanan yang tidak pernah mendapatkan pendidikan baik itu norma-norma ataupun etika dalam perilaku kehidupannya. Untuk itu perlu didesain model pendidikan yang memang harus disesuaikan dengan kondisi intelektual mereka. Perlu adanya standar yang khusus tanpa mengurangi esensi dari hakikat pendidikan itu sendiri.

4. Standar Penyelenggaraan

Pendidikan

Pelaksanaan pendidikan bagi Anak yang ditempatkan di Lapas belum memiliki standar yang sesuai dengan karakteristiknya. Lamanya proses terwujudnya satu standar pendidikan berpengaruh pada penerapan standar ini dalam penyelenggaraan pendidikan bagi anak, khususnya di LPKA. Minimnya anggaran mengakibatkan penyusunan standar yang berkaitan dengan kebutuhan pendidikan anak di LPKA dilakukan satu demi satu.

Anak yang berhadapan dengan hukum bukan sepenuhnya salah pada diri anak, namun kemungkinan masih lemahnya kontrol sosial dari agen sosialisasi yang menyebabkan anak melakukan penyimpangan. Metode dan program pembinaan yang ada selama ini kurang sesuai dengan kebutuhan dan kurang memberikan manfaat seperti yang mereka harapkan. Hal ini membuat mereka seringkali kehilangan minat mengikuti program kegiatan.

Masalah ini menunjukkan bahwa ada hal yang luput dari perhatian pihak lembaga pembinaan khusus anak maupun penyelenggaran dalam proses perencanaan program pembinaan bagi anak yang berada di dalam lembaga pemasyarakatan. Mereka seringkali melupakan proses analisis terhadap kebutuhan dan karakteristik masingmasing anak didik dalam 
penyelenggaraan suatu program pembinaan (Veriati, 2007). Seringkali suatu program kegiatan ditawarkan oleh pihak LSM atau lembaga lain di luar lembaga pemasyarakatan hanya bersifat insidentil dan tidak bersifat integratif. Berhenti pada satu kegiatan dan digantikan oleh kegiatan lain yang ditawarkan oleh lembaga yang berbeda (Veriati, 2007).

Dengan semakin meningkatnya jumlah anak-anak yang harus menjalani masa pidana di dalam lembaga pemasyarakatan anak maka semakin sering juga peranan lembaga pemasyarakatan anak dalam melakukan pembinaan terhadap mereka. Adapun tujuan diadakannya pembinaan agar mereka dapat menyadari kesalahan, tidak mengulangi perbuatannya untuk kedua kalinya dan dapat diterima kembali oleh masyarakat (Kumalasari, 2005). Aspek utama yang ditekankan dalam pembinaan di dalam Lembaga Pembinaan Khusus Anak adalah pada aspek kepribadian, salah satunya adalah pembinaan kemampuan intelektual (kecerdasan) yang dilakukan dalam bentuk pendidikan formal maupun nonformal (Kumalasari, 2005).

\section{KESIMPULAN}

Berdasarkan tulisan diatas dapat disimpulkan bahwa faktor-faktor yang mempengaruhi penyelenggaraan kebijakan sekolah filial bagi anak didik pemasyarakatan di Lembaga Pembinaan Khusus Anak Palembang antara lain: terbatasnya jumlah anak yang memenuhi persyaratan mengikuti pendidikan, khususnya lama pidana, minat anak yang rendah terhadap pendidikan, fasilitas dan sarana pendukung yang minim dan hampir tidak ada, rendahnya dukungan dari sekolah Anak sebelumnya. Selain itupun terdapat kendala-kendala penyelenggaraan pembinaan anak berbasis pendidikan yang diantaranya: kendala fasilitatif yang terdiri dari kondisi bangunan dan sarana penunjang pelaksanaan pendidikan, kendala permasalahan anggaran, kendala

peserta didik (anak didik pemasyarakatan) serta standar dari penyelenggaraan pendidikan.

Dengan adanya kebijakan sekolah filial merupakan bentuk perhatian dan kepedulian pemerintah terhadap pentingnya pendidikan bagi anak didik pemasyarakatan di Sumatera Selatan. Namun, program pendidikan ini terkendala dengan usia mereka yang menduduki bangku pendidikan yang tidak sesuai dengan usia pada umumnya. Hal ini dilatarbelakangi oleh permasalahan masa lalu mereka yang pernah melakukan pelanggaran hukum. Selain itu, ketika anak didik pemasyarakatan ini telah menyelesaikan hukumannya, bentuk penyesuaian pendidikan untuk masa depan mereka juga menjadi permasalahan karena latarbelakang yang berbeda. Hal ini perlu adanya kebijakan publik bagi anak didik pemasyarakatan terkhusus permasalahan pendidikan yang tepat guna mendorong dan mendukung terlaksananya pendidikan terbaik bagi anak. Sekolah filial yang ada di Palembang juga terkendala dengan sarana dan prasarana maupun anggaran untuk terselenggaranya kebijakan pembinaan secara efektif. Perbedaan 
lokasi antara anak didik pemasyarakatan laki-laki dan anak didik pemasyarakatan perempuan membuat pelaksanaan sekolah filial kurang berjalan dengan efektif.

Anak didik pemasyarakatan perempuan terkadang tidak mengikuti aktivitas pada sekolah filial yang dikarenakan lokasi maupun sarana dan prasarana yang menunjang mereka untuk mengikuti aktivitas sekolah yang masih minim. Dengan perubahan kurikulum pendidikan dari semula kejar paket $A, B$ dan $C$ berganti menjadi kurikulum yang digunakan pada sekolah induk yang menjadi induk pada sekolah filial menyebabkan jumlah anak didik yang ikut kegiatan pendidikan menjadi berkurang. Hal ini membuat kebijakan pembinaan melalui sekolah filial di lembaga pembinaan khusus anak Palembang belom dapat berjalan secara maksimal. Permasalahan anggaran juga menjadi salah satu masalah dalam terlaksananya kebijakan ini. Hal ini dikarenakan butuh transportasi maupun biaya lainnya dalam terselenggaranya kebijakan tersebut.

\section{DAFTAR PUSTAKA}

Grindle, Merilee S. 1980. Politics and Policy Implementation in the Third World. Princeton University Press. Princeton: New Jersey.

L.P. Sinambela. 2008. Reformasi Pelayanan Publik: Teori, Kebijakan dan Implementasi. Jakarta: Bumi Aksara.

Prakoso, Abintoro. 2013. Kriminologi dan Hukum Pidana. Yogyakarta: Laksbang Grafika.
Gunakarya, A. Widiada. 1988. Sejarah

dan Konsepsi Pemasyarakatan.

Armico: Bandung.

\section{Artikel dan Jurnal}

Yuliyanto \& Yul Ernis. 2016. Lembaga Pembinaan Khusus Anak dalam Perspektif Sistem Peradilan Pidana Anak. Badan Penelitian dan Pengembangan Hukum dan Hak Asasi Manusia Kementerian Hukum dan Hak Asasi Manusia RI. Jakarta: Percetakan Pohon Cahaya. Cetakan Pertama Desember 2016.

Aprilianda, Nurini. 2014. Laporan Akhir Pengkajian Hukum tentang Model Pembinaan Anak berbasis Pendidikan Layak Anak dalam Sistem Pemasyarakatan. Pusat Penelitian dan Pengembangan Sistem Hukum Nasional Badan Pembinaan Hukum Nasional Kementerian Hukum dan Hak Asasi Manusia RI.

\section{Tesis}

Simanjuntak, Nofitri Anna Maria. 2009. Kualitas Pelayanan Kunjungan bagi Keluarga Warga Binaan Pemasyarakatan di Lembaga Pemasyarakatan Kelas I Tangerang-Banten. Fakultas Ilmu Sosial Ilmu Politik Departemen Ilmu Administrasi Program Pascasarjana.

Yatiman. 2005. Penyelenggaraan Pendidikan Formal di Lembaga Pemasyarakatan Anak (Studi Kasus di Lapas Anak Pria Tangerang). Program Studi Pengkajian Ketahanan Nasional Kekhususan Kajian Strategik Ketahanan Nasional Universitas Indonesia. 
Muh. Mehdi. 2008. Analisis Perubahan Organisasi Melalui Analisis SWOT (Kasus di Lembaga Pemasyarakatan Klas I Cipinang). Program Studi Pengkajian Ketahanan Nasional Program Pascasarjana Universitas Indonesia.

Oktafiansyah, Medi. 2009. Analisis Implementasi Kebijakan Bebas Peredaran Uang (BPU) di Lembaga Pemasyarakatan Klas IIA Salemba. Fakultas Ilmu Sosial Ilmu Politik Departemen Ilmu Administrasi Program Pascasarjana. Implementasi Kebijakan Optimalisasi Pembebasan Bersyarat bagi Narapidana di Lapas Klas I Cipinang Jakarta. Fakultas Ilmu Sosial Ilmu Politik Departemen Ilmu Administrasi Program Pascasarjana.

Sudaryati. 2007. Pemenuhan Hak Perawatan Rohani dan Jasmani bagi Anak Didik untuk Mewujudkan Lapas Anak yang "Ramah Anak" (Studi Kasus Lapas Anak Wanita Tangerang). Program Studi Pengkajian Ketahanan Nasional Program

Pascasarjana Universitas Indonesia.

Kumalasari, Ratna. 2005. Meningkatkan Kemampuan Petugas Pemasyarakatan dalam Memotivasi Belajar Anak Didik di Lapas Anak Pria Tangerang. Program Studi Psikologi Terapan Kekhususan Psikologi Kriminal Universitas Indonesia.

Veriati, Acik. 2007. Rancangan Modul Analisis Kemampuan Psikososial Remaja di LAPAS Anak Pria
Tangerang. Program Studi Psikologi Terapan Kekhususan Psikologi Kriminal Universitas Indonesia.

\section{Peraturan}

Keputusan Menteri Kehakiman Republik Indonesia Nomor: M.02-PK04.10. Tahun 1990 tentang Pola Pembinaan Narapidana/Tahanan Menteri Kehakiman Republik Indonesia. Diakses melalui website: http://icjr.or.id/peraturanpemerintah/ (diakses pada hari Minggu, 18 Maret 2018 pukul 13.25).

\section{Laman Berita}

Alex Noerdin: Sekolah Filial Terobosan Luar Biasa. Diakses melalui website:

http://pemprovsumsel.tribunne ws.com $/ 2016 / 08 / 22 /$ alexnoerdin-sekolahfilial-terobosanluar-biasa (diakses pada hari Kamis, 2 Agustus 2018 pukul 11.30).

Abdullah, Yudi. 2017. Lapas Anak Palembang Sediakan Sekolah Filial SD-SMA. Diakses melalui website:

https://sumsel.antaranews.com/ berita/312106/lapas-anakpalembang-sediakansekolahfilialsd-sma (diakses pada hari Kamis, 2 Agustus 2018 pukul 11.44).

Aprilianda, Nurini. 2014. Laporan Akhir Pengkajian Hukum tentang Model Pembinaan Anak berbasis Pendidikan Layak Anak dalam Sistem Pemasyarakatan. Pusat Penelitian dan Pengembangan Sistem Hukum Nasional Badan Pembinaan Hukum 
Nasional Kementerian Hukum dan Hak Asasi Manusia RI.

Diakses melalui website: www.bphn.go.id

https://www.google.com/search ?safe $=$ strict $\&$ client $=$ firefox-b d\&ei=WeNJXPmG8imwgPL45yoD $\mathrm{Q} \& \mathrm{q}=$ Kendalakendala+Penyeleng garaan+Pembinaan+Anak+berba sis+pendidikan+bphn.go.id\&oq= (diakses pada hari Kamis, 2 Agustus 2018 pukul 11.57).

Lapas Anak Palembang Minim Fasilitas

Pendidikan. 13 Maret 2015.

Diakses melalui website: https://skalanews.com/berita/n asional/daerah/213119-lapasanak-palembang-minim-fasilitaspendidikan (diakses pada hari Minggu, 18 Maret 2018 pukul 15.11). 